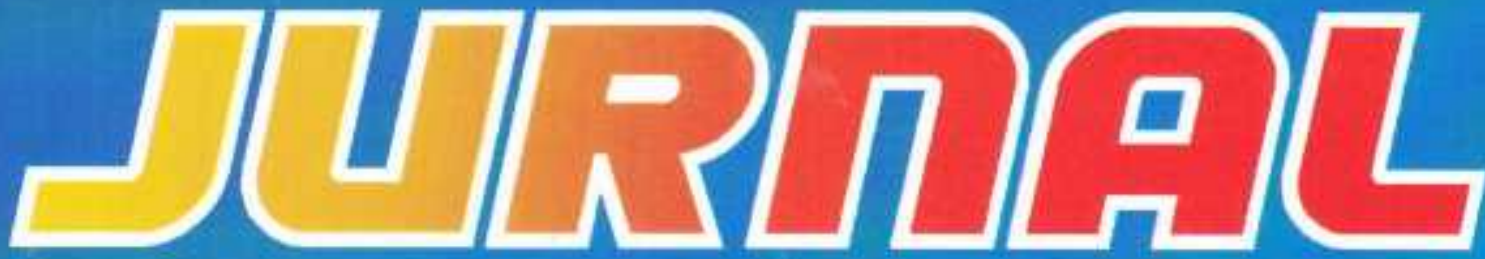

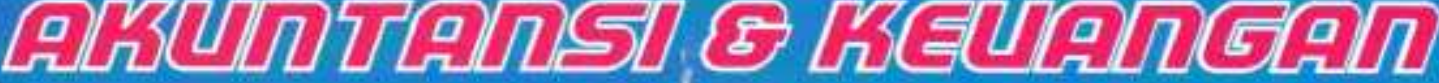

Volume 6, No. 1, Maret 2015

ISSN: $2087-2054$

Pengaruh Peran Acoount Representative Terhadap Tingkat Kepatuhan Wajib Pajak (Studi kasus pada KPP Pratama di Kota Bandar Lampung)

\section{Angrita Denziana \& Handi Sutanto}

Pengaruh Biaya Iklan Dan Biaya Penjualan Personal Terhadap Nilai Penjualan Pada PT Telekomunikasi Indonesia, Tbk.

\section{Chairul Anwar \& Rinna}

Relationship Executives Rewards With Financial Performance On Corporate Banking In Indonesia

\section{Haninun \& Putri Cagora Nisa}

Analisis Penerapan Metode Pengakuan Pendapatan Terhadap Laba Perusahaan Pada Pt. Coca Cola Distribusi Indonesia (Cabang Tanjung Karang)

\section{Herry Goenawan Soedarsa \& Surya Pandelima}

Pengaruh Tingkat Suku Bunga Simpanan Terhadap Jumlah Deposito Pada Pt. Bank Rakyat Indonesia (Persero) Tbk. Cabang Liwa

\section{Indrayenti \& Susanti}

Pengaruh Motivasi Terhadap Minat Mahasiswa Akuntansi Untuk Mengikuti Pendidikan Profesi Akuntansi (PPAK) Di Provinsi Lampung

\section{Rosmiaty Tarmizi \& Julia Restuti}

Pengaruh Kinerja Hutang Terhadap Nilai Perusahaan Pada Perusahaan Pertambangan Batubara Yang Terdaftar Di Bei Periode 2010-2013

\section{Khairudin \& Rico Tanto}

Pengaruh Profitabilitas, Ukuran Perusahaan, Debt To Equity Terhadap Ketepatan Waktu Penyampaian Laporan Keuangan (Studi Pada Perusahaan Asuransi Yang Terdaftar Di BEI)

\section{Riswan \& Tri Lestari Saputri}

Pengaruh Manajemen Laba Terhadap Kinerja Keuangan Pada Perusahaam Manufaktur Tahun 2011-2012

\section{Aminah \& Lidya Natasia Gunakan}




\section{Dewan Pembina}

Dr. Ir. M. Yusuf S. Barusman, M.B.A

Dr. Andala Rama Putra Barusman, S.E., M.A.Ec.

\section{Penanggung Jawab}

Dra. Rosmiaty Tarmizi, M.M.Akt. C.A

\section{Pimpinan Redaksi}

Dr. Angrita Denziana, S.E., M.M, Ak. C.A

\section{Sekretaris Redaksi}

Aminah, S.E., M.S.Ak

Khairudin, S.E., M.S.Ak

\section{Penyuting Ahli}

Prof. Dr. Jogiyanto Hartono, M.B.A. ( Universitas Gadjah Mada)

Tina Miniawati, S.E., M.B.A. (Universitas Trisakti)

Dr. Khomsiyah, S.E., M.M. (Universitas Trisakti)

Dr. Lindrianasari, S.E., M.Si.Akt. (Universitas Lampung)

Sujoko Efferin, Mcom (Hons), MA(Econ), Ph.D. (Universitas Surabaya)

\section{Penerbit}

Universitas Bandar Lampung

Fakultas Ekonomi dan Bisnis Program Studi Akuntansi

SENARAI-Jurnal Akuntansi \& Keuangan Terbit 2 kali setahun pada bulan Maret \&

September

Artikel yang dimuat berupa hasil riset Empiris dan telaah teoritis konsepsual yang kritis dalam kajian bidang akuntansi, auditing, perpajakan, dan keuangan.

\section{Alamat Redaksi}

Gedung G- Program Studi Akuntansi Fakultas Ekonomi dan Bisnis Universitas Bandar Lampung

Kampus A Jalan Z.A Pagar Alam No. 26 Labuan Ratu Bandar Lampung 35142

Telp: (0721) 701979, Fax: (0721) 701467, Email: Prodi.akuntansi@ubl.ac.id 


\section{JURNAL \\ AKUNTANSI \& KEUANGAN}

Volume 6, No. 1, Maret 2015

ISSN: 2087-2054

Pengaruh Peran Acoount Representative Terhadap Tingkat Kepatuhan Wajib Pajak

(Studi Kasus pada KPP Pratama di Kota Bandar Lampung)

Angrita Denziana \& Handi Sutanto

Pengaruh Biaya Iklan dan Biaya Penjualan Personal Terhadap Nilai Penjualan Pada PT

Telekomunikasi Indonesia, Tbk.

\section{Chairul Anwar \& Rinna}

Relationship Executives Rewards With Financial Performance On Corporate Banking In Indonesia

\section{Haninun \& Putri Cagora Nisa}

Analisis Penerapan Metode Pengakuan Pendapatan Terhadap Laba Perusahaan Pada PT. Coca Cola Distribusi Indonesia (Cabang Tanjung Karang)

Herry Goenawan Soedarsa \& Surya Pandelima

Pengaruh Tingkat Suku Bunga Simpanan Terhadap Jumlah Deposito Pada PT. Bank Rakyat Indonesia (Persero) Tbk. Cabang Liwa

Indrayenti \& Susanti

Pengaruh Motivasi Terhadap Minat Mahasiswa Akuntansi Untuk Mengikuti Pendidikan Profesi Akuntansi (PPAK) Di Provinsi Lampung

\section{Rosmiaty Tarmizi \& Julia Restuti}

Pengaruh Kinerja Hutang Terhadap Nilai Perusahaan Pada Perusahaan Pertambangan Batubara Yang Terdaftar Di BEI Periode 2010-2013

\section{Khairudin \& Rico Tanto}

Pengaruh Profitabilitas, Ukuran Perusahaan, Debt To Equity Terhadap Ketepatan Waktu Penyampaian Laporan Keuangan (Studi Pada Perusahaan Asuransi Yang Terdaftar Di BEI) Riswan \& Tri Lestari Saputri

Pengaruh Manajemen Laba Terhadap Kinerja Keuangan Pada Perusahaam Manufaktur Tahun 2011-2012

\section{Aminah \& Lidya Natasia Gunakan}




\section{JURNAL \\ AKUNTANSI \& KEUANGAN}

Volume 6, No. 1, Maret 2015

ISSN: 2087-2054

Daftar Isi

Halaman

$1-22$

Pengaruh Peran Acoount Representative Terhadap Tingkat Kepatuhan

Wajib Pajak (Studi kasus pada KPP Pratama di Kota Bandar Lampung)

Angrita Denziana \& Handi Sutanto

Pengaruh Biaya Iklan Dan Biaya Penjualan Personal Terhadap Nilai

Penjualan Pada PT Telekomunikasi Indonesia, Tbk.

Chairul Anwar \& Rinna

Relationship Executives Rewards With Financial Performance On

Corporate Banking In Indonesia

Haninun \& Putri Cagora Nisa

Analisis Penerapan Metode Pengakuan Pendapatan Terhadap Laba

Perusahaan Pada PT. Coca Cola Distribusi Indonesia (Cabang Tanjung

Karang)

Herry Goenawan Soedarsa \& Surya Pandelima

Pengaruh Tingkat Suku Bunga Simpanan Terhadap Jumlah Deposito Pada

PT. Bank Rakyat Indonesia (Persero) Tbk. Cabang Liwa

Indrayenti \& Susanti

Pengaruh Motivasi Terhadap Minat Mahasiswa Akuntansi Untuk

Mengikuti Pendidikan Profesi Akuntansi (PPAK) Di Provinsi Lampung

Rosmiaty Tarmizi \& Julia Restuti

Pengaruh Kinerja Hutang Terhadap Nilai Perusahaan Pada Perusahaan

Pertambangan Batubara Yang Terdaftar Di BEI Periode 2010-2013

\section{Khairudin \& Rico Tanto}

Pengaruh Profitabilitas, Ukuran Perusahaan, Debt To Equity Terhadap

Ketepatan Waktu Penyampaian Laporan Keuangan (Studi Pada Perusahaan Asuransi Yang Terdaftar Di BEI)

Riswan \& Tri Lestari Saputri

Pengaruh Manajemen Laba Terhadap Kinerja Keuangan Pada Perusahaam Manufaktur Tahun 2011-2012

Aminah \& Lidya Natasia Gunakan 


\section{JURNAL AKUNTANSI \& KEUANGAN}

Volume 6, No. 1, Maret 2015

ISSN: $2087-2054$

\section{Informasi Kebijakan dan Selingkung Berkala}

\section{Kebijakan editorial}

JURNAL Akuntansi \& Keuangan adalah sebuah berkala yang dipublikasikan oleh Universitas Bandar Lampung, yang bertujuan untuk menjadi wadah kreatifitas para akademisi, profesional, peneliti, dan mahasiswa di bidang Akuntansi dan Keuangan termasuk juga bidang Auditing, Sistem Informasi Akuntansi, Tata kelola Perusahaan, Perpajakan, Akuntansi Internasional, Akuntansi Managemen, Akuntansi Keperilakuaan, Pasar Modal dan lain sebagainya. Topik yang semakin meluas di bidang kajian riset Akuntansi diakomodir publikasinya di dalam berkala ini.

Paper yang akan dipublikasikan di dalam berkala JURNAL Akuntansi \& Keuangan harus ditulis di dalam bahasa Indonesia yang baik dan sesuai dengan EYD. Semua instrumen yang digunakan untuk memperoleh data penelitian harus dimasukkan di dalam lampiran paper penelitian, paling tidak, penulis bersedia memberikan klarifikasi atas instrumen yang digunakan saat ada permintaan dari peneliti lainnya.

\section{Sekretariat Editor Berkala}

Gedung F - Fakultas Ekonomi Universitas Bandar Lampung

Fakultas Ekonomi Program Studi Akuntansi

Kampus A Jalan Z.A. Pagar Alam No. 26 Labuhan Ratu Bandar Lampung 35142

$$
\text { Telp.: (0721) 701979, Fax.: (0721) 701467, Email: }
$$

\section{Petunjuk penulisan}

Artikel yang dikirim ke JURNAL Akuntansi \& Keuangan harus mengikuti petunjuk seperti berikut:

1. Naskah merupakan naskah asli yang belum pernah diterbitkan atau sedang dilakukan penilaian pada berkala lain. Naskah ditulis dalam bahasa Indonesia dengan jarak 1 spasi, sepanjang 20-30 halaman kertas A4 dengan tipe huruf Times New Roman.. Naskah dikirim atau diserahkan ke sekretariat JURNAL Akuntansi \& Keuangan rangkap satu disertai disket berikut dengan biodata penulis dan alamat lengkap (kantor dan rumah) pada lembaran yang terpisah dari halaman pertama artikel.

2. Judul naskah dapat ditulis dengan menggambarkan isi pokok tulisan, dan atau ditulis secara ringkas, jelas, dan menarik. 
3. Nama Penulis disertai catatan kaki tentang profesi dan lembaga tempat penulis bekerja dalam naskah yang telah diterima untuk diterbutkan.

4. Abstrak ketik satu spasi, tidak lebih dari 250 kata dalam bahasa Inggris. Abstrak memuat tujuan penelitian, isu, permasalahan, sampel dan metode penelitian, serta hasil dan simpulan (jika memungkinan).

5. Pendahuluan beriksikan uraian tentang latar belakang masalah, ruang lingkup penelitian, dan telaah pustaka yang terkait dengan permasalahan yang dikaji, serta rumusan hipotesis (jika ada). Uraian pendahuluan maksimum $10 \%$ total halaman.

6. Untuk penelitian kuantitatif,

a. Telaah Literatur dan Pengembangan Hipotesis memuat paling tidak satu buah teori yang menjadi dasar pemikiran penelitian. Hipotesis dikembangkan menggunakan asumsi dasar teori dan hasil penelitian sebelumnya. Telah literatur maksimum $40 \%$ total halaman.

b. Metodologi Penelitian meliputi uraian yang rinci tentang bahan yang digunakan, metoda yang dipilih, teknik, dan cakupan penelitian. Uraian bahan dan metoda maksimum $20 \%$ total halaman.

7. Untuk penelitian kualitatif menyesuaikan dengan metodologi kualitatif.

8. Hasil dan Pembahasan merupakan uraian obyektif dari-hasil penelitian dan pembahasan dilakukan untuk memperkaya makna hasil penelitian. Uraian hasil dan pembahasan minimum $25 \%$ total halaman.

9. Simpulan yang merupakan rumusan dari hasil-hasil penelitian. Harus ada sajian dalam satu kalimat inti yang menjadi simpulan utama. Simpulan maksimum 10\% dari keseluruhan lembar artikel.

10. Referensi (Daftar Pustaka) ditulis berurutan berdasarkan alphabetical, disusun menggunakan suku kata terakhir dari nama penulisnya, atau institusi jika dikeluarkan oleh organisasi.

a. Buku: nama penulis, tahun penerbitan, judul lengkap buku, penyunting (jika ada), nama penerbit, dan kota penerbitan.

b. Artikel dalam buku: nama penulis, tahun penerbitan, judul artikel/tulisan, judul buku, nama penyunting, kota penerbitan, nama penerbit, dan halaman.

c. Terbitan berkala: nama penulis, tahun penerbitan, judul tulisan, judul terbitan (bila disingkat, sebaiknya menggunakan singkatan yang baku), volume, nomor, dan halaman.

d. Artikel dalam internet: nama penulis, judul, dan situsnya.

e. Tabel diberi nomor dan judul dilengkapi dengan sumber data yang ditulis dibawah badan tabel, diikuti tempat dan waktu pengambilan data.

f. Ilustrasi dapat berupa gambar, grafik, diagram, peta, dan foto diberi nomor dan judul.

11. Setiap referensi yang digunakan di dalam naskah artikel menggunakan petunjuk yang dirujuk pada The Indonesian Journal of Accounting Research, sebagai berikut:

A. Kutipan dalam tubuh naskah paper harus disesuaikan dengan contoh berikut:

I. Satu sumber kutipan dengan satu penulis (Brownell, 1981).

II. Satu sumber kutipan dengan dua penulis (Frucot dan Shearon, 1991).

III. Satu sumber kutipan dengan lebih dari satu penulis (Hotstede et al., 1990).

IV. Dua sumber kutipan dengan penulis yang berbeda (Dunk, 1990; Mia, 1988).

V. Dua sumber kutipan dengan satu penulis (Brownell, 1981, 1983).

VI. Dua sumber kutipan dengan satu penulis diterbitkan pada tahun yang sama (Brownell, 1982a, 1982b). 
VII. Sumber kutipan dari lembaga harus dinyatakan dengan menggunakan akronim institusi (FASB, 1994)

B. Setiap artikel harus menulis referensi menggunakan panduan berikut:

I. Referensi harus tercantum dalam urutan abjad dari nama belakang penulis atau nama lembaga.

II. Referensi harus dinyatakan dengan urutan sebagai berikut: penulis (s) nama, tahun publikasi, judul kertas atau buku teks, nama jurnal atau penerbit dan nomor halaman. Contoh:

a) Amerika Akuntansi Association, Komite Konsep dan Standar Laporan Keuangan Eksternal. 1977. Pernyataan tentang Teori Akuntansi dan Teori Penerimaan. Sarasota, FL: AAA.

b) Demski, J. S., dan D. E. M. Sappington. 1989. Struktur hirarkis dan akuntansi pertanggungjawaban, Jurnal Akuntansi Penelitian 27 (Spring): 40-58.

c) Dye, R. B., dan R. Magee. 1989. Biaya Kontijensi untuk perusahaan audit. Kertas kerja, Northwestern University, Evansto, IL.

d) Indriantoro, N. 1993. Pengaruh Penganggaran Partisipatif Terhadap Prestasi Kerja dan Kepuasan Kerja dengan Locus of Control dan Dimensi Budaya sebagai Moderating Variabel. Ph.D. Disertasi. University of Kentucky, Lexington.

e) Naim, A. 1997. Analisis Penggunaan Akuntansi Biaya Produk Dalam Keputusan Harga oligopolistik. Jurnal Ekonomi Dan Bisnis Indonesia 12 (3): 43-50.

f) Porcano, T. M. 1984a. Keadilan distributif dan Kebijakan Pajak. Akuntansi Ulasan 59 (4): 619-636.

g) -------. 1984b. Pengaruh Persepsi Kebijakan Pajak Niat Investasi Perusahaan. The Journal of American Association Perpajakan 6 (Fall): 719.

h) Pyndyk, R. S. dan D. L. Rubinfield. 1987. Model ekonometrik \& Forecasts Ekonomi, 3rd ed. NY: McGraw-Hill Publishing, Inc.

12. Author(s) harus melampirkan CV, alamat email, alamat korespondensi dan pernyataan yang menyatakan pasal tersebut tidak sedang disampaikan kepada atau diterbitkan oleh jurnal lain dalam email tersebut dan /atau pos. 


\title{
PENGARUH MOTIVASI TERHADAP MINAT MAHASISWA AKUNTANSI UNTUK MENGIKUTI PENDIDIKAN PROFESI AKUNTANSI (PPAK) DI PROVINSI LAMPUNG
}

\author{
Rosmiaty Tarmizi \\ Julia Restuti \\ (Universitas Bandar Lampung) \\ email:rosmiati@ubl.ac.id \\ email: julia_blackjack@yahoo.co.id
}

\begin{abstract}
This study aims to analyze and provide empirical evidence about the effect of motivation on student interest in accounting to follow accounting education program. Hypothesis in this research is motivation influence of student interest in accounting to follow accounting education program. The data used in this study is primary data. The primary data used by using questionnaire obtained from 90 respondents is $S 1$ students majoring in accounting at the University of Lampung Province who have taken 120 credits or who was in the seventh semester. Samples were obtained by proportional sampling. The data analysis technique used in this study is a simple regression analysis and hypothesis testing t test using SPSS 18.0 for windows. Results of the study was the hypothesis is accepted as motivation affect the interest of the education of accounting students to follow the accounting profession.
\end{abstract}

Keywords: student's motivation, accounting education program

\section{Pendahuluan}

Keinginan menjadi seorang akuntan yang profesional merupakan cita-cita yang dimiliki oleh semua mahasiswa program studi akuntansi. Kebanyakan mahasiswa berasumsi bahwa seorang akuntan memiliki masa depan yang baik di dalam pekerjaannya, dan juga adanya anggapan bahwa seorang akuntan akan sangat dibutuhkan oleh banyak organisasi atau perusahaan di Indonesia. Secara umum terdapat beberapa pilihan yang dapat diambil oleh mahasiswa akuntansi setelah menyelesaikan pendidikan strata satu (S1). Pertama, sarjana akuntansi dapat langsung bekerja sebagai seorang karyawan perusahaan swasta, karyawan instansi pemerintah, ataupun berwiraswasta. Kedua, sarjana akuntansi dapat melanjutkan pendidikan strata dua (S2). Ketiga, dapat melanjutkan pendidikan profesi untuk menjadi akuntan publik dengan mengikuti Pendidikan Profesi Akuntansi (PPAk).

Pendidikan Profesi Akuntansi (PPAk) merupakan pendidikan tambahan bagi seorang lulusan Sarjana Ekonomi Jurusan Akuntansi yang ingin mendapatkan sebutan Akuntan (Akt). Pendidikan Profesi Akuntansi (PPAk) memiliki tujuan untuk menghasilkan akuntan profesional dengan standardisasi kualitas akuntan di Indonesia. UU No.34 Tahun 1954 mengatur mengenai pemakaian gelar akuntan di Indonesia, yang menyatakan gelar akuntan 
dapat dipakai oleh lulusan jurusan akuntansi pada Perguruan Tinggi Negeri atau lulusan suatu ujian yang ijazahnya sama dengan Perguruan Tinggi Negeri.

Pada tahun 1979 diterbitkan surat keputusan Dirjen Dikti (Direktorat Jenderal Pendidikan Tinggi) yang mengatur tentang Ujian Negara Akuntansi (UNA). Penyelenggaraan UNA ditujukan bagi lulusan Perguruan Tinggi Negeri dan Perguruan Tinggi Swasta yang belum secara otomatis mendapatkan gelar akuntan. Sebagai bentuk peningkatan kualitas dari lulusan akuntansi, maka dikeluarkan Surat Keputusan Menteri Pendidikan Nasional Nomor 179/U/2001 tentang Pengangkatan Panitia Ahli Persamaan Ijazah Akuntan, serta ditanda tanganinya MOU antara Ikatan Akuntansi Indonesia (IAI) dengan Dirjen Dikti Depdiknas atas pelaksanaan Pendidikan Profesi Akuntan, yang pada akhirnya Pendidikan Profesi Akuntansi di Indonesia terealisasi.

Berakhir juga pemberian gelar akuntan (Akt) kepada lulusan S1 program studi akuntansi di Perguruan Tinggi tertentu pada tanggal 31 agustus 2004, maka sejak itulah lulusan S1 akuntansi tidak lagi bergelar akuntan. Dengan adanya PPAk, gelar akuntan bukan hanya dimonopoli Perguruan Tinggi Negeri tertentu yang diberi hak istimewa oleh Depdiknas, tetapi sudah menjadi hak bersama bagi semua Perguruan Tinggi. Pada tahun 2011 akhirnya dirumuskan undang-undang yang mengatur mengenai profesi akuntan publik, yang ditetapkan menjadi UU No.5 tahun 2011 yang mengatur tentang jasa akuntan publik yang bertujuan memberikan keyakinan bagi pengguna atas hasil evaluasi atau pengukuran informasi keuangan dan nonkeuangan berdasarkan suatu kriteria. Selain mengatur tentang profesi akuntan publik, undang-undang ini juga mengatur tentang Kantor Akuntan Publik (KAP) yang merupakan wadah bagi akuntan publik dan bentuk usaha KAP yang sesuai dengan profesi akuntan publik, yaitu independensi dan tanggung jawab profesional terhadap hasil kerjanya.

Mengikuti Pendidikan Profesi Akuntansi (PPAk) memang bukan suatu kewajiban bagi sarjana ekonomi jurusan akuntansi, tetapi dengan mengikuti PPAk diharapkan para sarjana akuntansi dapat menambah ilmu serta pengalaman yang dimiliki, juga diharapkan akan munculnya orang-orang yang memiliki kualitas didalam pekerjaannya sebagai seorang akuntan yang profesional. Para peserta program PPAk adalah para sarjana lulusan strata 1 (satu) pada jurusan akuntansi yang tentunya ingin mendalami secara lebih spesifik bidangbidang akuntansi tertentu. Dalam menjalani program PPAk tersebut diperlukan suatu motivasi yang membuat mereka memilih untuk mengikuti tiap mata kuliah, bahkan mempertahankan keinginan untuk meneruskannya hingga selesai. 


\section{Tinjauan Pustaka}

\subsection{Teori yang mendasari Motivasi}

Supardi dan Anwar (2004) mengatakan motivasi adalah keadaan dalam pribadi seseorang yang mendorong keinginan individu untuk melakukan kegiatan-kegiatan tertentu guna mencapai tujuan. Motivasi yang ada pada seseorang akan mewujudkan suatu perilaku yang diarahkan pada tujuan mencapai sasaran kepuasan. Jadi, motivasi bukanlah yang dapat diamati tetapi adalah hal yang dapat disimpulkan adanya karena sesuatu perilaku yang tampak. Menurut Marbawi (2002) motivasi dibagi menjadi dua, yakni motivasi internal dan motivasi eksternal. Motivasi internal adalah tenaga pendorong yang mendorong manusia untuk bertindak atau suatu tenaga di dalam diri manusia yang menyebabkan manusia bertindak, sedangkan motivasi eksternal adalah daya dorong yang timbul dari luar diri seseorang dan umumnya bertujuan sebagai motivasi kerja. Djaali (2008:109) menyebutkan bahwa individu yang memiliki motivasi yang tinggi memiliki karakteristik sebagai berikut:

1. Menyukai situasi atau tugas yang menuntut tanggung jawab pribadi.

2. Memilih tujuan yang realistis.

3. Mencari situasi atau pekerjaan dimana ia memperoleh umpan batu dengan segera dan nyata untuk menentukan baik atau tidaknya hasil atau pekerjaannya.

4. Senang berkerja sendiri dan bersaing untuk mengungguli orang lain.

5. Mampu menggunakan pemuasan keinginannya demi masa depan yang lebih baik.

6. Tidak tergugah untuk sekedar mendapatkan uang, status atau keunggulan, tetapi lambang prestasilah yang dicarinya.

Sardiman (2011:85) menjelaskan motivasi akan mendorong seseorang untuk melakukan sesuatu, karena motivasi memiliki fungsi seperti:

1. Mendorong manusia untuk berbuat, jadi sebagai penggerak atau motor yang melepaskan energi. Motivasi dalam hal ini merupakan motor penggerak dari setiap kegiatan yang akan dikerjakan.

2. Menentukan arah perbuatan, yakni kearah tujuan yang hendak dicapai. Dengan demikian motivasi dapat memberikan arah dan kegiatan yang harus dikerjakan sesuai dengan rumusan tujuannya.

3. Menyeleksi perbuatan yakni menentukan perbuatan-perbuatan apa yang harus dikerjakan yang serasi guna mencapai tujuan, dengan menyisihkan perbuatan-perbuatan yang tidak bermanfaat lagi bagi tujuan tersebut. 
Berdasarkan dari beberapa pengertian motivasi di atas, dapat penulis simpulkan bahwa motivasi adalah sebuah tenaga yang muncul dari dalam diri manusia dan menjadi pendorong seseorang untuk bertindak melakukan sesuatu yang diinginkan demi mencapai tujuan tertentu.

\section{Minat}

Menurut Sanjaya (2006) minat merupakan suatu kecenderungan yang menyebabkan seseorang berusaha untuk mencari ataupun mencoba aktivitas aktivitas dalam bidang tertentu. Minat juga diartikan sebagai sikap positif terhadap aspek-aspek lingkungan. Selain itu, minat juga merupakan kecenderungan yang tetap untuk memperhatikan dan menikmati suatu aktivitas disertai dengan rasa senang. Minat berkaitan dengan perasaan suka atau senang dari seseorang terhadap sesuatu objek. Hal ini seperti dikemukakan oleh Slameto (2003:180) yang menyatakan bahwa minat sebagai suatu rasa lebih suka dan rasa keterikatan pada suatu hal atau aktivitas, tanpa ada yang menyuruh. Minat pada dasarnya adalah penerimaan akan suatu hubungan antara diri sendiri dengan sesuatu di luar diri, semakin kuat atau dekat hubungan tersebut semakin besar minat.

Menurut Sardiman (2011:76) minat diartikan sebagai suatu kondisi yang terjadi apabila seseorang melihat ciri-ciri atau arti sementara situasi yang dihubungkan dengan keinginankeinginan atau kebutuhan-kebutuhannya sendiri. Oleh karena itu, apa yang dilihat seseorang sudah tentu akan membangkitkan minatnya sejauh apa yang dilihat itu mempunyai hubungan dengan kepentingannya sendiri, sedangkan menurut Surya (2003:100) minat dapat diartikan sebagai rasa senang atau tidak senang dalam menghadapi suatu objek. Menurut Djaali (2008) yang menyebutkan bahwa ada tiga faktor yang mendasari timbulnya minat seseorang yaitu :

1. Faktor dorongan yang berasal dari dalam

Kebutuhan ini dapat berupa kebutuhan yang berhubungan dengan jasmani dan kejiwaan.

2. Faktor motif sosial

Timbulnya minat sesorang dapat didorong dari motif sosial yaitu kebutuhan untuk mendapatkan penghargaan dari lingkungan dimana mereka berada.

3. Faktor emosional

Faktor ini merupakan ukuran intensitas seseorang dalam menaruh perhatian terhadap sesuatu kegiatan atau objek tertentu.

Berdasarkan beberapa pendapat para ahli di atas dapat disimpulkan bahwa minat merupakan kecenderungan pada seseorang yang ditandai dengan rasa senang atau 
ketertarikan pada objek tertentu. Dengan adanya pemusatan perhatian kepada objek tersebut dan keinginan untuk terlibat dalam aktivitas objek tertentu, sehingga mengakibatkan seseorang memiliki keinginan untuk terlibat secara langsung aktivitas tertentu, karena dirasakan bermakana bagi dirinya dan ada keinginan yang di tuju.

\section{Pendidikan Profesi Akuntansi}

Pendidikan Profesi Akuntansi (PPAk) adalah pendidikan tambahan pada pendidikan tinggi setelah program sarjana Ilmu Ekonomi. PPAk sendiri diselenggarakan oleh beberapa perguruan tinggi khususnya Perguruan Tinggi Negeri (PTN). Berdasarkan Surat Keputusan (SK) Mendiknas No.179/U/2001, lulusan sarjana strata 1 (S1) jurusan akuntansi berkesempatan menempuh Pendidikan Profesi Akuntansi di perguruan tinggi yang telah ditunjuk oleh Direktorat Jendral Pendidikan Tinggi. Mereka yang telah menempuh Pendidikan Profesi Akuntansi ini berhak memperoleh sebutan profesi Akuntan (Akt), dan juga semakin berpeluang meniti karir sebagai auditor pemerintahan, auditor internal, akuntan sektor publik, akuntan manajemen, akuntan pendidik, akuntan perpajakan, akuntan keuangan, maupun akuntan sistem informasi. Sebutan Akuntan ini secara spesifik merupakan persyaratan untuk mengikuti Ujian Sertifikasi Akuntan Publik (USAP). Ujian Sertifikasi Akuntan Publik ini merupakan suatu tes untuk menjadi seorang akuntan publik dengan gelar akuntan publik bersertifikasi. Tanpa mendapatkan gelar akuntan terlebih dahulu melalui PPAk, maka seseorang tidak dapat mengikuti tes USAP tersebut.

Pendidikan Profesi Akuntansi (PPAk) adalah usaha yang bertujuan untuk menghasilkan akuntan profesional dengan standardisasi kualitas akuntan di Indonesia. Kurikulum dan silabus PPAk sudah disusun untuk memenuhi persyaratan untuk menjadi akuntan profesional yang ditentukan oleh Internacional Financial Accounting Committee (IFAC).

\subsection{Penelitian Terdahulu dan Hipotesis}

Penelitian ini adalah replikasi dari penelitian Ismail dan Lestari (2012) yang berjudul "Pengaruh Motivasi Terhadap Minat Mahasiswa Akuntansi Untuk Mengikuti Pendidikan Profesi Akuntansi (PPAk) Di Perguruan Tinggi Sumatera Utara”. Penelitian tersebut menguji pengaruh dari motivasi kualitas (X1), motivasi karir (X2), dan motivasi ekonomi (X3) terhadap minat mahasiswa. Hasil dari penelitian Ismail dan Lestari menyatakan bahwa motivasi kualitas dan motivasi karir secara parsial berpengaruh signifikan terhadap minat mahasiswa untuk mengikuti PPAk, sedangkan motivasi ekonomi secara parsial tidak 
berpengaruh secara signifikan terhadap minat mahasiswa mengikuti PPAk, dan secara simultan diketahui bahwa motivasi kualitas, motivasi karir dan motivasi ekonomi bersamasama berpengaruh secara signifikan terhadap minat mahasiswa untuk mengikuti PPAk.

Penelitian lain juga dilakukan oleh Yuneriya, Sarwono, dan Kristianto (2013) dengan judul "Pengaruh Motivasi, Persepsi dan Lama Pendidikan Terhadap Minat Mahasiswa Untuk Mengikuti Pendidikan Profesi Akuntansi”. Penelitian tersebut menguji pengaruh dari motivasi karir (X1), motivasi ekonomi (X2), motivasi kualitas (X3), persepsi (X4), dan lama pendidikan (X5) terhadap minat mahasiswa (Y). Hasil dari penelitian Yuneriya, Sarwono dan Kristianto menyatakan bahwa motivasi karir, motivasi kualitas, motivasi ekonomi dan lama pendidikan secara parsial berpengaruh secara signifikan terhadap minat mahasiswa untuk mengikuti PPAk, sedangkan persepsi secara signifikan tidak berpengaruh terhadap minat mahasiswa mengikuti PPAk.

\section{Metodelogi Penelitian}

\subsection{Populasi dan Sampel}

Populasi dalam penelitian ini adalah seluruh mahasiswa jurusan akuntansi S1 di Perguruan Tinggi di Provinsi Lampung yang telah mengambil mata kuliah sebanyak 120 sks atau mahasiswa yang berada pada semester 7. Penelitian ini mengunakan teknik proportional sampling. Proportional sampling adalah teknik pengambilan sampel yang memperhatikan pertimbangan unsur-unsur atau kategori dalam populasi penelitian (Sugiyono, 2007). Rumus proportional sampling sebagai berikut (Sugiyono, 2007).

$\mathrm{n}_{1=} \frac{n}{N} \times \mathrm{N} 1$

Keterangan :

$\mathrm{n}_{1} \quad=$ Banyaknya sampel di setiap Perguruan Tinggi

$\mathrm{n} \quad=$ Banyaknya populasi di setiap Perguruan Tinggi

$\mathrm{N} \quad=$ Banyaknya populasi seluruh mahasiswa

N1 = Banyaknya sampel penelitian 
Populasi Mahasiswa Akuntansi S1 Semester 7

Perguruan Tinggi di Provinsi Lampung

\begin{tabular}{|l|l|l|}
\hline Perguruan Tinggi & $\mathbf{n}$ & $\mathbf{n}_{\mathbf{1}}$ \\
\hline Universitas Lampung & 115 & 12 \\
\hline Universitas Bandar Lampung & 105 & 11 \\
\hline Universitas Malahayati & 28 & 4 \\
\hline Universitas Muhammadiyah Metro & 70 & 7 \\
\hline Universitas Megow Pak Tulang Bawang & 50 & 6 \\
\hline Institut Informatika Dan Bisnis Darmajaya & 190 & 20 \\
\hline STIE Lampung & 22 & 3 \\
\hline STIE Gentiaras & 34 & 4 \\
\hline UMITRA & 135 & 14 \\
\hline STIE Satu Nusa & 85 & 9 \\
\hline Total Mahasiswa & $\mathbf{8 3 4}$ & $\mathbf{9 0}$ \\
\hline
\end{tabular}

Data diolah : 2014

\subsection{Jenis dan Sumber Data}

Jenis data yang digunakan dalam penelitian ini adalah jenis data kuantitatif. Data kuantitatif adalah data yang dinyatakan dalam bentuk angka, merupakan hasil dari perhitungan dan pengukuran. Sumber data penelitian ini merupakan data yang dikumpulkan langsung oleh peneliti dari para responden dengan meggunakan kuisioner dan bukan berasal dari pengumpulan data yang pernah dilakukan sebelumnya yang biasa disebut dengan data primer.

\subsection{Metode Pengumpulan Data}

Metode pengumpulan data yang digunakan dalam penelitian ini dengan menggunakan kuisioner. Data diperoleh dengan cara membagikan langsung kuisioner kepada mahasiswa atau secara personal pada Perguruan Tinggi di Provinsi Lampung. Skala yang digunakan dalam penelitian ini menggunakan skala likert. Skala likert adalah skala yang didasarkan pada penjumlahan sikap responden dalam merespon pernyataan berkaitan dengan indikatorindikator suatu konsep atau variabel yang sedang diukur (Sanusi, 2011:59).

\subsection{Definisi Operasional}

Berikut ini akan dijelaskan mengenai variabel dalam penelitian ini:

1. Motivasi (X) adalah dorongan dari dalam diri manusia. Dalam penelitian ini motivasi digunakan sebagai variabel independen. Dengan indikator yaitu: Motivasi Kualitas, Motivasi Karir dan Motivasi Ekonomi. 
2. Minat (Y) adalah kecenderungan pada seseorang yang ditandai dengan rasa senang atau ketertarikan pada objek tertentu disertai dengan adanya pemusatan perhatian kepada objek tersebut. Minat pada penelitian ini merupakan variabel dependen kaitannya dengan minat mahasiswa untuk mengikuti PPAk. Dengan indikator yaitu: Dorongan Dari Dalam, Motif Sosial dan Emosional.

\subsection{Model Penelitian dan Pengujian Statistika Pengujian Kualitas Data}

Pengujian kualitas data menggunakan uji validitas dan reliabilitas. Validitas adalah suatu ukuran yang menunjukan tingkat-tingkat kevalidan suatu instrumen (Arikunto, 2005:144). Uji reliabilitas adalah uji untuk memastikan apakah kuesioner penelitian yang akan dipergunakan untuk mengumpulkan data variabel penelitian reliabel atau tidak. Kuesioner dikatakan reliabel jika kuesioner tersebut dilakukan pengukuran berulang, akan medapatkan hasil yang sama. Pada penelitian ini menggunakan teknik perhitungan Cronbach Alpha, dimana variabel dikatakan reliable jika memberikan nilai Cronbach Alpha $>0,60$ (Ghozali, 2009:45).

\section{Analisis Regresi Sederhana}

Regresi sederhana ini menyatakan hubungan kausalitas antara dua variabel dan memperkirakan nilai variabel terikat berdasarkan nilai variabel bebas. Persamaan yang digunakan untuk memprediksi nilai variabel Y disebut dengan persamaan regresi (Sanusi, 2011:131). Bentuk umum dari persamaan regresi dinyatakan dengan persamaan matematika yaitu :

$\mathbf{Y}=\mathbf{a}+\mathbf{b X}$

Keterangan :

Y : Minat Mahasiswa mengikuti PPAk

a : Konstanta

b : Koefisiensi Regresi

X : Motivasi

\section{Uji Hipotesis}

\section{Koefisien Determinasi $\left(\mathbf{R}^{2}\right)$}

Koefisien determinasi $\left(\mathrm{R}^{2}\right)$ digunakan untuk mengukur seberapa jauh kemampuan variabel bebas dalam menerangkan variabel terikat (Setiaji, 2004:20). Rumus yang digunakan untuk menhitung koefisien determinasi adalah sebagai berikut.

$K d=r^{2} \times 100 \%$ 
Keterangan :

Kd : Koefisien determinasi

$\mathrm{r}^{2} \quad$ : Koefisien korelasi

Uji t

Uji t dilakukan untuk mengetahui pengaruh variabel independen secara individu terhadap variabel dependen, dengan menganggap variabel lainnya konstan. Penetapan untuk mengetahui hipotesis diterima atau ditolak, yaitu membandingkan $t$ hitung dengan $t$ tabel (Sanusi, 2011:146).

Jika nilai $\mathrm{t}_{\text {hitung }}<\mathrm{t}_{\text {tabel }}$ maka $\mathrm{H}_{\mathrm{o}}$ diterima dan $\mathrm{H}_{\mathrm{a}}$ ditolak.

Jika nilai $t_{\text {hitung }}>t_{\text {tabel }}$ maka $\mathrm{H}_{\mathrm{o}}$ ditolak dan $\mathrm{H}_{\mathrm{a}}$ diterima.

\section{Hasil dan Pembahasan}

\subsection{Gambaran Umum Responden}

Peneliti menyebarkan 90 kuisioner kepada 90 responden ke 10 Perguruan Tinggi di Provinsi Lampung untuk mengetahui pengaruh motivasi terhadap minat mahasiswa akuntansi untuk mengikuti pendidikan profesi akuntansi. Kuisioner yang kembali dan dapat diolah menggunakan SPSS 18.0 adalah sebanyak 79 kuisioner.

\subsection{Hasil Uji Validitas dan Reliabilitas}

Hasil uji validitas dapat dilihat dari Corrected Item-Total Correlation yang menunjukan korelasi antara skor total item yang dapat digunakan untuk menguji validitas instrument. Hasil pengujian menunjukan bahwa seluruh pernyataan dinyatakan valid karena nilai Corrected Item-Total Correlation lebih besar dari $\mathrm{r}_{\text {tabel }}$ yaitu 0,19.

Hasil uji reliabilitas dapat dilihat dari nilai Cronbach's Alpha. Nilai Cronbach's Alpha untuk variabel motivasi sebesar $0,850>0,60$ dan variabel minat sebesar 0,877 $>0,60$ sehingga dapat dinyatakan bahwa item reliabel.

\section{Analisis Regresi Linier Sederhana}

Berikut adalah tabel hasil pengelolaan data menggunakan SPSS 18.0.

\section{Hasil Uji Regresi Linier Sederhana}

\begin{tabular}{|c|c|c|c|c|c|c|}
\hline \multicolumn{7}{|c|}{ Coefficients $^{a}$} \\
\hline \multirow{2}{*}{\multicolumn{2}{|c|}{ Model }} & \multicolumn{2}{|c|}{$\begin{array}{l}\text { Unstandardized } \\
\text { Coefficients }\end{array}$} & \multirow{2}{*}{$\begin{array}{c}\begin{array}{c}\text { Standardized } \\
\text { Coefficients }\end{array} \\
\text { Beta }\end{array}$} & \multirow[b]{2}{*}{$\mathrm{t}$} & \multirow[b]{2}{*}{ Sig. } \\
\hline & & B & Std. Error & & & \\
\hline \multirow[t]{2}{*}{1} & (Constant) & 14.601 & 3.615 & & 4.039 & .000 \\
\hline & Motivasi & .597 & .089 & .607 & 6.702 & .000 \\
\hline
\end{tabular}

Sumber: hasil output program SPSS 18.0, 2014

$$
\mathrm{Y}=\mathbf{1 4 . 6 0 1}+\mathbf{0 . 5 9 7} \mathrm{X}
$$


Persamaan tersebut menyatakan bahwa motivasi berpengaruh terhadap minat mahasiswa akuntansi untuk mengikuti pendidikan profesi akuntansi dimana. Koefisien regresi b menghasilkan nilai sebesar 0.597 , nilai ini menunjukan bahwa jika terjadi perubahan pada motivasi maka akan menyebabkan perubahan minat mahasiswa sebesar 0.597 pada konstanta sebesar 14.601 .

\subsection{Pengujian Hipotesis}

\section{Uji Koefisien Determinasi $\left(\mathbf{R}^{2}\right)$}

\section{Hasil Uji Koefisien Determinasi $\left(\mathbf{R}^{2}\right)$}

Model Summary ${ }^{\text {b }}$

\begin{tabular}{|c|r|r|r|r|}
\hline Model & & & Adjusted R \\
Square & \multicolumn{2}{c|}{$\begin{array}{c}\text { Std. Error of the } \\
\text { Estimate }\end{array}$} \\
\hline 1 & $\mathrm{R}$ & $\mathrm{R}$ Square & .360 & 3.966 \\
\hline
\end{tabular}

Sumber: hasil output program SPSS 18.0, 2014

Berdasarkan hasil yang didapat dari perhitungan SPSS 18.0 diperoleh nilai determinasi $\left(\mathrm{R}^{2}\right)$ motivasi sebesar 0,368 . Hal ini menggambarkan $36,8 \%$ minat mahasiswa akuntansi untuk mengikuti pendidikan profesi akuntansi disebabkan oleh adanya motivasi yang muncul, sedangkan sisanya sebesar $63,2 \%$ dipengaruhi oleh beberapa faktor lain diluar variabel penelitian ini.

\section{Uji t}

\section{Hasil Uji t}

Coefficients $^{\mathrm{a}}$

\begin{tabular}{|c|c|c|c|c|c|c|}
\hline \multirow{2}{*}{\multicolumn{2}{|c|}{ Model }} & \multicolumn{2}{|c|}{$\begin{array}{l}\text { Unstandardized } \\
\text { Coefficients }\end{array}$} & \multirow{2}{*}{$\begin{array}{c}\text { Standardized } \\
\text { Coefficients } \\
\text { Beta }\end{array}$} & \multirow[b]{2}{*}{$\mathrm{t}$} & \multirow[b]{2}{*}{ Sig. } \\
\hline & & $\mathrm{B}$ & Std. Error & & & \\
\hline & $($ Constan $t)$ & 14.601 & 3.615 & & 4.039 & .000 \\
\hline & Motivasi & .597 & .089 & .607 & 6.702 & .000 \\
\hline
\end{tabular}

Sumber: hasil output program SPSS 18.0, 2014

Dari tabel 4.11 dapat dilihat $\mathrm{t}$ hitung sebesar 6,702 > t tabel yaitu 1,66 dan signifikan $0,000 \leq 0,05$ maka $\mathrm{H}_{0}$ ditolak dan Ha diterima. Dengan demikian hipotesis yang menyatakan bahwa terdapat pengaruh antara motivasi terhadap minat mahasiswa akuntansi untuk mengikuti pendidikan profesi akuntansi (PPAk) di Provinsi Lampung dapat diterima dan benar adanya. 


\section{Kesimpulan dan Saran}

\subsection{Kesimpulan}

Tujuan dari penelitian ini adalah meneliti pengaruh motivasi terhadap minat mahasiswa akuntansi untuk mengikuti pendidikan profesi akuntansi (PPAk) di Provinsi Lampung.

Dari pengujian yang telah dilakukan dapat ditarik kesimpulan, yaitu :

1. Berdasarkan hasil analisis data yang telah dilakukan, diketahui bahwa motivasi berpengaruh terhadap minat mahasiswa akuntansi untuk mengikuti Pendidikan Profesi Akuntansi (PPAk) di Provinsi Lampung.

2. Minat mahasiswa untuk mengikuti Pendidikan Profesi Akuntansi sedikit dipengaruhi oleh motivasi hal ini dapat terlihat dari perhitungan uji koefisien determinasi pada $R$ square.

\subsection{Saran}

1. Peneliti selanjutnya dapat menggunakan sampel yang lebih banyak, karena dalam penelitian ini sampel masih terbatas.

2. Peneliti selanjutnya dapat menambahkan variabel penelitian seperti lama pendidikan dan biaya pendidikan.

3. Peneliti selanjutnya dapat menggunakan metode interview untuk mendapatkan komunikasi dua arah dan mendapatkan jawaban yang pasti dan jujur dari para responden.

\section{Daftar Pustaka}

Arikunto, Suharsimi. 2005. Prosedur Penelitian Suatu Pendekatan Praktek, Jakarta: PT Rineka Cipta.

Djaali. 2008. Psikologi Pendidikan. Jakarta ; Bumi Akasara

Ghozali, Imam. 2009. Aplikasi Analisis Multivariate Dengan Program SPSS. Edisi ke Empat. Penerbit: Universitas Dipinogoro.

Ismail, Lestari B. 2012. Pengaruh Motivasi Terhadap Minat Mahasiswa Akuntansi Untuk Mengikuti Pendidikan Profesi Akuntansi (PPAk) Di Perguruan Tinggi Sumatera Utara. Jurnal Keuangan dan Bisnis Vol. 4 No. 2.

Marbawi. 2002. Motivasi dan Kepuasan Kerja Karyawan dan Dosen Universitas Malikussaleh Lhoksumawe. Journal of Economic E-MABIS vol 2 no. 5

Sanjaya, W. 2006. Strategi Pembelajaran. Jakarta: Kencana Prenada Media Group.

Sanusi, Anwar. 2011. Metodelogi Penelitian Bisnis. Penerbit: Salemba Empat, Malang.

Sardiman,A.M. 2011. Interaksi dan Motivasi Belajar Mengajar. Jakarta: PT. Raja Grafindo Persada. 
Setiaji, B. 2004. Panduan Riset Dengan Pendekatan Kuantitatif. Surakarta : PPS Universitas Muhammadiyah.

SK Mendiknas No. 180/P/2001 Tentang Pengangkatan Ahli Persamaan Ijazah Akuntan.

Slameto. 2003. Belajar dan Faktor-Faktor yang Mempengaruhinya. Jakarta: Rineka Cipta. SPSS vs LISREL : Sebuah Pengantar, Aplikasi Untuk Riset.

Sugiyono. 2007. Statistika Untuk Penelitian. Bandung: Alfabeta.

Supardi dan Anwar, S. 2004. Dasar-dasar Perilaku Organisasi. Yogyakarta:UII Press. Rineka Cipta.

Surya, M. 2003. Psikologi Konseling. Bandung: CV. Pustaka Bani Quraisy.

Undang-undang Nomor 34 Tahun 1954 Tentang Pemakaian Gelar Akuntan.

Undang-undang Nomor 5 Tahun 2011 Tentang Akuntan Publik.

Yuneriya, Aris, Djoko. 2013. Pengaruh Motivasi, Persepsi, dan Lama Pendidikan Terhadap Minat Mahasiswa Untuk Mengikuti Pendidikan Profesi Akuntansi. Jurnal Ekonomi dan Kewirausahaan Vol. 13 No. 1. 